Paediatrica Indonesiana $16: 355-360$. Sept. - Oct. 1976.

From the Denartment of Child Health, Dr. Kariadi Hospual/Medical School University of Diponegoro, Semarang

\title{
Intrathecal Hydrocortisone in the Treatment of Tuberculous Meningitis (Preliminary Report)
}

HARSOYO N., MOELJONO S. TRASTOTENOJO, SOEJONO, DEDY ABUBAKAR and INDRA WARMAN.

\section{Abstract}

A trial on the treatment of tuberculous meningitis with intrathecal hydrocortisone, beside INH, PAS, and Streptomycin, performed at the Dr. Kariadi General Hospital in October 1972, is reported. Eighteen patients were treated, giving good results; $5.6 \%$ mortality were noted. A great number of complications of optic nerve atrophy (61.1\%) were found and $22.2 \%$ with early atrophy ecovered. The results are better compared with those of Choremis et al. (1957) who found a mortality of $13.7 \%$ among 29 patients with tuberculous meningitis treated in the same way, except P.A.S.

Received 14th. Dec. 1974. 


\section{Introduction}

Tuberculous meningitis is the most serious complication of primary tuberculosis, which has caused a great number of deaths (Boyd, 1956; Gunadi Santoso and Prajogo, 1968; Lincoln, 1947; Lincoln and Sewell, 1963; Lincoln and Sifontes, 1953; Miller, 1963).

The mortality rate can be reduced by intrathecal hydrocortisone (Bulkeley, 1953; Choremis et al., 1957; Gosh et al., 1971; Roussel, 1972; Szabo et al., 1957). At the Dr. Kariadi General Hospital, Department of Child Health, Medical School, University of Diponegoro, clinical trials were performed to evalu. ate the effectiveness of intrathecal hydrocortisone against tuberculous meningitis, in addition to Streptomycin injected intramuscularly, Iso Nicotinic Hydrazide and Para Amino Salicylic acid orally.

\section{Material and methods}

Included in this trial were all patients under 14 years of age admitted to the Department of Child Health, Dr. Kariaji General Hospital, in October 1972, with the diagnosis of tuberculous meningitis. The diagnosis was based on the clinical history, physical examination and cerebro-spinal fluid examination. The following examinations were done to confirm the diagnosis: Tuberculin test with alt tuberculin; chest and skull X-ray; cerebro-spinal fluid biochemistry and culture; gastric lavage; Levinson test and Tryptophan test.
According to Levinson (1951) cerebro-spinal fluid of tuberculous $n$ ningitis was clear or opalescent; cell count was 10 to 350 per ml., the gl cose was less than $50 \mathrm{mg} . \%$ and th protein was increased (Boyd, 195 Gunadi Santoso and Prajogo, 1968 Nelson, 1967; Lincoln and Sewel 1963; Lincoln and Sifontes, 1953; Mi ler, 1963).

It was divided into 3 groups acco ding to the following stages :

1. Stage I : The prodromal stag of irritability.

2. Stage II : The transitional stag of increased intra-cranial pressure an meningeal symptoms.

3. Stage III : The terminal stag of paralysis and coma (Nelson, 1967 Lincoln and Sewell, 1963; Udani et al 1972).

The treatment given was :

1. Streptomycin: $50 \mathrm{mg} / \mathrm{kg}$ body weight per day intramuscularly, unti 30 times or more, according to the patient's condition.

4. Hydrocortisone intrathecally: 10 $15 \mathrm{mg}$ per day for 10 days, then $10 \mathrm{~m}$ twice weekly for 3 weeks.

Systemic Costicosteroid treatment was given in conjunction with the preceding treatment:

$2 \mathrm{mg} . / \mathrm{kg}$. body-weight under th age of 3 years;

$1.5 \mathrm{mg} . / \mathrm{kg}$. body-weight between the age of 3 and 8 years;
$1 \mathrm{mg} . / \mathrm{kg}$. body-weight in older children.

This daily injection, intramuscular or intravenous, should be continued for 2 to 3 weeks (according to the general clinical improvement and the normalization of cerebro-spinal fluid). Then the dose was reduced by $5 \mathrm{mg}$ every 15 days to reach a dose of $10 \mathrm{mg}$ in older children and $5 \mathrm{mg}$ in younger children.

Then the dose was gradually decreased by $1 \mathrm{mg}$ every day until the treatment was stopped.

Evaluation of the cerebro-spinal fluid during the intrathecal treatment was done daily, particularly cells, glucose and protein levels. On admission rontgenograms of the chest and skull were made, and repeated after 30 days. Every patient was consulted to the Ophthalmologic and Neurologic Departments.

\section{Results}

Eighteen patients were admitted, consisting of 11 boys and 7 girls; the average age was between 8 months and 14 years. All of the patients $(77.7 \%)$ were under 5 years, most of them were 1 to 2 years old $(38.8 \%)$. The youngest case was an 8-month-old boy and the oldest a 13-year and 9-month-old boy. Most of the patients were in a poor condition and their body-weight was below normal $(55.5 \%)$.Fifty per cent of the tuberculin tests were positive.

According to the stage of the disease there were :

1. Stage I: 2 patients (11.1\%)

2. Stage II : 6 patients $(33.3 \%)$

3. Stage III : 10 patients $(55.5 \%)$
Chest X-ray, revealed $66.8 \%$ pulmonary tuberculosis, $16.6 \%$ miliary tuberculosis, and $6.6 \%$ were normal. Protein and sugar values of the cerebro-spinal fluid were not rapidly restored to normal. Protein returned to normal in an average of 76.9 days. An average of 44.4 days was required for the abnormally low sugar'to return to normal. The average hospitalization of the patients was 120.2 days. Three patients had gone home before the treatment was ended. One patient died within the sixth week of admission. The cause of death was aspiration pneumonia.

Complications :

- Neurological complications: Hemiparesis $=4$

Multiple palsies $=5$

Hydrocephalus $=0$

- Ophthalmological complications: Optic atrophy $=11$

Third nerve atrophy $=1$

- Ear complication : Slight hearing loss $=1$

Mental disorder was not examined.

\section{Discussion}

Eighteen children suffering from tuberculous meningitis were treated with intrathecal hydrocortisone, in ad. dition to the anti-tuberculous drugs (I.N.H., P.A.S., and Streptomycin), According to some reports, the mortality rate of tuberculous meningitis in Surabaya (1964-1966) was 53.6\% (Gunadi Santoso and Prajogo, 1968) and at the Dr. Kariadi Hospital between 
1969 - 1971 was $48.6 \%$. Fifty-nine patients with tuberculous meningitis were studied by Ghosh et al. (1971) for 3 years.

Tahernia (1967) found 38 patients during 6 years.

We have found $61.1 \%$ boys and $38.9 \%$ girls in our study, but we have not read about any prevalence in boys in the literature (Boyd, 1956; Gunadi Santoso and Prajogo, 1968; Nelson, 1967; Lincoln, 1947; Lincoln, and Sifontes, 1953; Miller, 1963). $77.7 \%$ of the patients were under 5 years, most of them $(38.9 \%)$ between 1 to 2 years, the youngest was 8 months. One case under 4 months was found by Lincoln and Sewell (1963). Half of the patients $(55.5 \%)$ were in a bad condition.

Most of them were admitted during the terminal stage.

Clinical experiences in Surabaya (1964-1966) indicated that $89.7 \%$ of the patients were in a bad condition (Gunadi Santoso and Prajogo, 1968). In our study the tuberculous. meningitis patients had tuberculosis of the lung $(66.8 \%)$, and miliary tuberculosis (16.6\%). According to Lincoln (1963) most of the tuberculous meningitis patients had tuberculosis of the lung (94\%). Nelson (1967) found miliary tuberculosis in $25-30 \%$ of his cases. Tuberculous meningitis at the St. Sophie Hospital during a period of 2 years, caused a mortality rate of (Choremis et al., 1957):

$16.6 \%$ : in cases treated with Streptomycin and INH.
$17.2 \%$ : in cases where cortisone i tramuscularly was added to the abo treatment.

$13.7 \%$ : in cases where cortisone was changed with hydrocortisone intr thecally.

The mortality rate was $6.7 \%$. A sim lar study was done by Ghosh et a (1971) between 1966-1969, at the Saf. sarjang Hospital, New Delhi where 20 children received INH, Streptomycin intramuscularly and hydrocortisone in trathecally; the mortality rate was $55.0 \%$

Ou. patients died in the terminal stage; Ghosh et al. (1971) had 3 patients in the 2nd stage and 8 patients in 3rd stage. Choremis et al. (1957) had also 4 patients who died in the third stage. The most frequent sequelae found was optic nerve atrophy $(61.1 \%)$, of these $22.2 \%$ with early atrophy which beca. me normal and $38.9 \%$ with irreversible atrophy. Ghosh et al. (1971) had 4 pati. ents $(20 \%)$ with optic nerve atrophy. Many patients with tetraparesis recove red with physio-therapy.

Kapur (1969) in a study of 103 pati. ents (98 of which were treated with steroids) concluded that the addition of ste roids to the treatment of tuberculous meningitis seemed to have significantly reduced the mortality of tuberculous meningitis. She compared this result with 117 patients treated in 1962, of whom only 38 patients had received steroids. Ashby and Grant (1955), Bulkeley (1953), reported a similar improved survival in steroid treated pa: tients, attributing this to a reduction of the spinal block. Lepper and Spies (1963), on the other hand; were unable to detect any effect after 14 days of steroid therapy in 19 patients, compared with controls. In their double-blind study of 23 patients with dexamethasone as an adjunct to the treatment in 11 patients, he concluded that despite a striking influence of dexamethasone on the cerebro-spinal fluid, an improved survival was related to an amelioration of cerebral oedema. Steroid treatment could lower the cerebro-spinal fluid protein level in this disorder (Choremis et al., 1957; Johnson et al., 1957; Shane and Riley, 1953).

\section{Acknowledgement}

We wish to express our gratitude to Les Luboratories Roussel Paris, for the supply of hydrocortisone for injection in our study, which is Lyophilized Hydrocortisone Roussel, and also to the Departments of Neurology, Ophthalmology, Radiclogy, and Otolaryngology, for their special examinations.

\section{REFERENCES}

ASHBY, M. and GRANT, M. : Tuberculuus meningitis treated with cortisone. Laricet i : 65 (1965).

2. BULKELEY, H.C.M. : Tuberculous me. ningitis treated with $\mathrm{ACTH}$ and Isoniazi de. Br. med, J. 2 : 1127 (1953)

3. BOYD, G. : Tuberculous meningitis in children. J. Dis. Child. $91: 477$ (1956).

4. CHOREMIS, C.; PAPADATOS, C. and CARCOULAS, A. : Intra-thecal hydrocoitisone in the treatment of tuberculous meningitis. J. Pediatr. $50: 133$ (1957).

5. GHOSH; S.; SESHADRI, R, and JAIN, R.C. : Evaluation of corticosteroids in the treatment of tuberculous meningitis. Arch. Dis. Childh. 46 : 51 (1971).

\section{GUNADI SANTOSO and PRAJOGO}

E. : Meningitis tuberculosa; pengalaman klinik. Kumpulan naskah Konika I, 1968.

. JOHNSON, J.R.; FURSTENBERG, N.E.; PATTERSON, R.; SCHOCH, H.K. and DAVEY, W.N. : Corticotropin and adrenal steroids as adjuncts to the treatment of tuberculous meningitis. Annals Int Med. $46: 316$ (1957).

8. KAPUR, $S_{+}$: Evaluation of treatment of tuberculous meningitis since the use of steroids as an adjuvant. Indian Pediatr. 6 : 166 (1969).

9. Leading article : Tuberculous meningitis in children. Br. Med. J, 1 : 1(1971).

10. LEPPER, M.H. and SPIES, H.W. : The present status of the treatment of tuberculosis of the central nervous system. Annals New York Acad. Sciences 106: 106 (1963).

11. LEVINSON, A. : Meningitis. Brennean's Pract. Pediatr. 4 : 8 (1951).

12. LINCOLN, E.M.: Tuberculous meningitis. Am. Rev. Tuberc. 56 : 79 (1947).

13. LINCOLN, E.M. and SEWELL, E.M. Tuberculous meningitis in children. (McGraw-Hill, New York 1963).

14. LINCOLN, E.M. and SIFONTES, J.E. Tuberculous meningitis in children. Med. Clin. N. Am. 37 : 345 (1953). 
15. MILLER, F.J. : Tuberculosis in children. (Churchill, London 1963).

16. NELSON, W.E. : Tuberculous meningitis in Textbook of Pediatrics. 8th ed. (Saunders, Philadelphia 1967).

17. O'TOOLE, R.D.; THORNTON, G.P.; MUKHERJEE, M.K. and NATH, R.L. : Dexamethasone in tuberculous meningitis. Annals Int. Med. 70 : 39 (1969).

18. RATNER, D. : Treatment of tuberculous meningitis. Pediatr. 29 : 676 (1957).

19. ROUSSEL : Hydrocortisone in the treatment tuberculous meningitis. Brochure, 1972.

20. SHANE, S.J. and RILEY, C. : Tuberculous meningitis. New Engl. J. Med. 249 : 829 (1953).

21. SZABO G.; STERK, V.V. and BERMAN S. : Tuberculous meningitis treated with hydrocortisone and cortisone. Paediatr. 19 : 580 (1957).
22. TAHERNIA, A.C. : Tuberculous menj ngitis. Modern diagnosis, treatment and prognosis as exemplified in 38 cases in Southern Iran. Clin. Ped. 6 : 173 (1967)

23. UDANI, P.M. : Tuberculous in children Pediatr. Clin. India $3: 163$ (1968).

24. UDANI, P.M.; PAREKH, U.C. and DAS TUR, D.K. : Some neurological syndro me in CNS Tuberculosis. Neurol. Indis I : 63 (1972).

25. UDANI, P.M.; PAREKH, U.C. and DAS TUR, D.K. : Tuberculosis of central nervous system. Indian Pediatr. 10 : 64? (1972).

26. VOLJAVEC, B.F. and CORPE, R.F. The influence of corticosteroid hormone in the treatment of tuberculous meningi tis in Negroes. Am. Rev. Regis. Dis. 81 539 (1960).

27. WASZ - HOCKERT, O. : Result of the treatment of 191 children with tuber culous meningitis in; $1949 \cdot 1954$. Act: Pediatr. 141 : 7 (1962). 